\title{
26 Research Soure \\ Identification of Bacteria in Infected Wounds Using Electronic Nose: A Systematic Review
}

\author{
José William Araújo do Nascimento ( $\nabla$ jwan@cin.ufpe.br ) \\ Computer Center, Federal University of Pernambuco (Cin-UFPE) \\ Geicianfran da Silva Lima Roque \\ Computer Center, Federal University of Pernambuco (Cin-UFPE) \\ Rafael Roque de Souza \\ Catholic University of Pernambuco \\ Michael Lopes Bastos \\ Computer Center, Federal University of Pernambuco (Cin-UFPE) \\ Isabel Cristina Ramos Vieira Santos \\ University of Pernambuco (UPE) \\ Leandro Maciel Almeida \\ Computer Center, Federal University of Pernambuco (Cin-UFPE)
}

\section{Research Article}

Keywords: Artificial Intelligence, Machine Learning, Wound infection

Posted Date: February 24th, 2022

DOI: https://doi.org/10.21203/rs.3.rs-1318064/v1

License: (c) (i) This work is licensed under a Creative Commons Attribution 4.0 International License. Read Full License 


\section{Abstract \\ Background}

Effective management of patients with infected wounds is a crucial concern. A delay in prescribing the appropriate antibacterial agent can lead to life-threatening clinical complications. Thus, the electronic nose technique (eNose) can provide a diagnostic aid tool that allows rapid and accurate identification of pathogens.

\section{Results}

This study examines the effectiveness of using eNoses to aid in the diagnosis of bacterially infected wounds. The systematic search in the literature retrieved 3,326 publications, of which 97 were for a complete review, and of these, 09 comprised the sample of this study. These studies involved the analysis of seven types of wounds, the most common being the infected skin wound. The most frequent bacteria were $P$. aeruginosa, E. coli and methicillinsusceptible Staphylococcus aureus (MSSA). The average accuracy of the eNoses in identifying these microorganisms was $95.13 \%$ for the training set and $91.5 \%$ for the test set, including the ability to differentiate between bacteria of the same genus but sensitive or resistant to antibiotics. Among the Artificial Intelligence techniques used to classify the models, the Support Vector Machine (SVM) was the most commonly used in the experiments.

\section{Conclusion}

The eNoses devices observed may have broad applicability in aiding diagnosis of wound infection through their high efficacy values. However, further research needs to explore the reduction of interferences in the accuracy of the application of Machine Learning algorithms.

\section{Background}

Over the centuries, wounds have been a severe public health problem and can be present in all stages of life, regardless of gender, age, and social status [1]. These injuries are caused mainly by trauma, surgical procedures, and chronic diseases such as diabetes mellitus, vascular changes, and malignancies [2]. It is estimated that in the United States of America, about 8.2 million people have a wound. At the same time, in Europe, this number ranges from 1.5 to 2 million individuals and, although prevalence studies are scarce, it is estimated that a rate of 1 to $2 \%$ of the general population in developed countries has an acute or chronic wound $[3,4,5]$. Furthermore, research indicates that patients with some type of wound have been occupying hospital beds in Europe at a rate that varies from $27-50 \%$, permeating high costs to health systems, such as the United Kingdom, where about 5 billion were spent. between 2012 to 2013 [6].

Wounds have a high rate of infection, delaying the healing process of these lesions and consequently increasing morbidity and mortality in these patients [2]. The infectious agents responsible for these infections in both superficial and deep wounds include Staphylococcus aureus, Staphylococcus epidermidis, Escherichia coli, Pseudomonas aeruginosa, Streptococcus pyogenes and Enterococcus faecalis [7, 8, 9].

The current main methods for diagnosing infection in cutaneous wounds are culture-based and molecular-based, with empirical antibiotic use as the gold standard in treatment initially, with subsequent collection of wound culture, 
which takes around 48 to 72 hours. In addition to time issues, the results obtained from the collection and analysis of swabs can convey something misleading, since some clinical microbiology laboratories use culture methods that detect planktonic bacteria or are not always suitable for anaerobic species. Associated with this situation, it should be noted that wound cultures can, in several situations, fail to identify bacteria that are protected within a biofilm, causing inconclusive results that are subject to misinterpretation [10].

In this sense, some disadvantages related to the clinical outcome of the patient from this methodology can be identified. First, due to the long-time interval between collection and results, it is common for physicians to prescribe antibiotic therapy intuitively, which in some cases can be incorrect, resulting in worsening of the infection and an increase in the length of hospital stay. It is also noteworthy that this situation associated with an excessive prescription of empiric antibiotics can contribute to the occurrence of antimicrobial resistance (AMR) [10].

Molecular methods are alternatives to bacterial cultures, but problems with this technique are suboptimal sensitivity, cost, and limitations of primers in diagnostic kits [11]. Mass spectrometry-based methods, which can identify bacterial species in about $90 \%$ of cases, have not been very feasible to the reality in many countries, especially developing ones, given the high fixed costs of this technology [12]. Clinical judgment of wound infection by nurses and physicians is also often used as a diagnostic criterion. However, wound infection's clinical signs and symptoms are often masked in patients with complex wounds [13].

Thus, new methods to aid in the diagnosis of infected wounds have been proposed in recent years, especially in the field of Volatile Organic Compounds (VOC) analysis. In this regard, an excellent technological resource in computer science is the use of the Electronic Nose (eNose), a non-invasive, painless, inexpensive sampling technique that can be easily performed on sick patients, children, and the elderly [14].

An eNose is a device designed to detect and discriminate complex odors using a set of chemical sensors. They are instruments based on the biological process of odor interpretation, working similarly with sensors that replace the receptors in the human nose, transmitting a signal to a program that will process it and simulate brain interpretation [15]. When an odor is presented to eNose, a physical change is modulated in the sensors, which the transducers detect and then convert into an electrical signal to create a slight impression. The increase and decrease of the signal depending on some parameters like the nature of the odor, reaction, diffusion between the odor, sensors, and environmental conditions [16].

An eNose system refers to a sample handling suite, a gas sensor suite, and a pattern recognition and analysis system. The sample handling system allows samples to be presented to the sensors in a controlled and orderly manner. Within this matrix, each specific sensor will have a unique sensitivity and selectivity profile. It is noteworthy that these data collected by eNose are electrical signals generated from the interaction of VoCs with the surfaces that are in contact with the sensors, being then stored in the form of time series. In developing the database, partitions are performed to define one set of samples for training the model, and the second to evaluate its performance to select the best performing model (test data set for validation). As a group, the responses provide a unique pattern (or olfactory impression) for VOCs in the headspace of the test sample [17].

Since their development in the mid-1920s, eNoses have been widely used in various areas of healthcare since odor is a crucial feature in various clinical conditions. For example, ammoniacal urine odor is associated with a bladder infection, acetone-scented breath is often related to diabetes mellitus, and people with diphtheria often have a sweet-smelling sweat odor [18]. From this perspective, electronic nose technology has come under much stimulus. 
Many studies in medicine have started to analyze the effectiveness of eNose in various conditions, such as in the diagnosis of obstructive airway diseases [19], pneumonia [20], diagnosis of lung cancer [20], and COVID-19 [21]. In the field of skin wounds, the use of eNose to diagnose infections has been widely discussed in the scientific community. It is because odors are standard features of infected wounds, and to prevent complications, it is essential to detect the infection in a timely and accurate manner [22]. Using an eNose, an expressive variety of biological samples can be analyzed more quickly, involving little sample preparation. To our knowledge, to date, no study has gathered scientific evidence about the use of eNoses to detect the actual presence of wound infections.

Thus, the main aim of this review is to analyze the effectiveness of the use of eNoses applied in the diagnosis of bacteria-infected wounds. We developed a primary research question to address the reported objective: What is the effectiveness of using eNoses applied in the diagnosis of bacterially infected wounds? In order to answer this question clearly and objectively, seven secondary research questions were developed that guided the results found in this systematic review. The seven secondary questions are:

- Q1: In what year, source, and publication channel were the articles published?

- Q2: What are the type and characteristics of eNoses used in infected wound diagnosis?

- Q3: What methodology, time, and sample size were used for data collection in the experiments involving VOCs and eNoses?

- Q4: What types of wounds and bacteria had their VOCs analyzed in eNoses?

- Q5: What Artificial Intelligence techniques were used to analyze VOC released by bacteria in infected wounds?

- Q6: How effective are eNoses in diagnosing infected wounds?

- Q7: What are the main gas sensors used in eNoses applied to infected wound diagnosis?

To answer these secondary questions, we will answer the primary research question and thereby understand how eNoses can be instrumental in use in infected wounds. It will help future research be improved and this new method of wound infection diagnosis to be scaled up into randomized clinical trials and consequently used in hospital settings.

\section{Methods}

This systematic review was conducted based on the Preferred Reporting Items for Systematic Reviews and MetaAnalyses (PRISMA) method [23]. It is noteworthy that systematic reviews are the gold standard for synthesizing and analyzing scientific evidence due to their methodological rigor, being widely used to support the development of clinical practice guidelines and inform decision-making. Thus, to improve the quality of this study, we applied the PRISMA checklist with 27 items that are recognized as one of the best standards for reviewers in reporting the analyzed results [23].

\section{Search strategy}

Four electronic databases were used in a systematic search, including PubMed, ACM Digital Library, Scopus, and IEEE Xplore Digital Library. The search strategy included three keyword categories: wound, artificial intelligence, and electronic nose; to increase the sensitivity of the search (more excellent coverage), synonyms for each term were added. The number of synonyms added to a search string provides a trade-off between sensitivity and precision. A large number of synonyms increases the sensitivity when searching for articles. In the present review, we chose to 
increase sensitivity at the expense of dealing with a large number of related search papers. These search terms used to generate the search string can be seen in Table 1. Database search strategies are available in additional files.

Table 1. Construction of the search sequence.

\begin{tabular}{|ll|}
\hline Descriptors & Search terms \\
Electronic nose & Electronic nose \\
\cline { 2 - 2 } Artificial Intelligence & Enose \\
\cline { 2 - 2 } & Volatifile organic compounds \\
\hline Wound & Machine Learning \\
& Wound \\
\hline & Wound Infection \\
\hline
\end{tabular}

\section{Inclusion and exclusion criteria}

Studies that met the following criteria were included: 1) Full-text journal/conference articles; 2) Articles were published between January 2017 to April 2021; 3) Studies published in English, Spanish, and Portuguese; Articles dealt with any wound types; 4) Articles analyzed VOCs in bacteria- infected wounds.

Studies were excluded if they met the following criteria: 1) The title, abstract or full text of the article was not relevant to the guiding question of this research; 2) Studies that used eNose to identify VoCs not related to infected wounds; 3) Analysis of VOCs using molecular methods; 4) Theses, book chapters, letter to editors, reports, book reviews, review studies or meta-analysis; 5) Articles with full text not available.

\section{Data extraction}

After the survey in the databases, the studies were submitted to data identification and analysis stages. For the development of this phase, a Google Sheets table shared among the researchers of this work was used. The table contains the following fields in the following order: ID (an increasing counter for identifying the article), Authors, Title, Year of Publication, Place of Publication, Database, and Publication Link. Each researcher was responsible for different databases, split to add a similar number of articles to the table.

The last activity in this phase was the removal of article duplicates, i.e., the removal of articles that were returned by more than one database so that only one instance of the same article remains in the table. The table resulting from this step contains the set of selected articles used in the second step.

In this second screening step, all article titles and abstracts were examined based on the reviewers' main objectives of selecting relevant studies. Subsequently, the full texts of relevant studies were examined thoroughly by two reviewers, and if there were any disagreements between them, a third reviewer would make the final decision.

Thus, the filtered articles in the databases were analyzed (n: 3,326) and duplicated immediately excluded, considering only the first to be identified. Thus, after 126 duplicates were removed, 3,200 studies were analyzed for 
their titles and abstracts, and 3,103 were excluded after incorporating the eligibility criteria.

In the next step, the eligible studies ( $\mathrm{n}$ : 97) were read in their entirety by two researchers independently. After the analyses and resolution of discrepancies between the assessments, 09 articles were included in the final study sample for data extraction. A summary of the steps performed is shown in Figure 1.

Thus, classified and interpreted the results; the reviewers considered specific categories. The authors developed a data extraction form to manage the information obtained. The classifications considered for the quanti-qualitative analysis of the articles is represented in Figure 2. Then, the in- formation obtained from the articles was summarized and entered into the extraction.

\section{Quality Assessment}

The quality assessment aims to provide a measure of confidence for a given study, such that this confidence can make a valuable contribution to the systematic review. This assessment was conducted by two independent reviewers, with disagreements resolved by consensus. If this was not possible, a third reviewer was sought. The Critical Appraisal Skills Programme (CASP) criteria were used to evaluate the quality of the articles. Thus adapt the CASP to the research problem at hand; different CASP checklists were used. The criteria were grouped into a single script consisting of eleven questions (additional files). In addition, three categories of criteria were proposed: Quality of Reporting, which is related to the description of the research conducted; Rigor, related to the methodology of the study; and Relevance, related to the application of what was developed by the study.

The classify each category, and the following score was used for each question: 0 (no or not informed) and 1 (yes). The included studies were divided into two categories: level A (score between 6 and 10), being considered of good methodological quality and reduced bias; nível B (up to 5 points), meaning satisfactory methodological quality, but with considerable risk of bias. In the present study, we chose not to exclude articles classified as level B and decided to present the two quality levels quantitatively.

\section{Results}

\section{General characteristics of the studies}

The cited methodology's systematic search resulted in nine studies included in the final sample, which used the eNose to identify bacteria present in infected wounds. An overview of the studies is presented in Table 2, whose temporal distribution shows a higher frequency of publications in the years 2017 (n: 03) and 2019 (n: 03). 66.7\% (n: 06) of the experimental studies were conducted in China, while the rest were conducted in Spain, Finland, and the Netherlands.

As one way to verify the reliability of these studies, it was found that $77.8 \%(n: 07)$ of the research was published in journals/conferences classified as Qualis A1 (highest level) by the Coordination for the Improvement of Higher Level Personnel (CAPES) in Brazil. At the global level, the Journal Citation Reports (JCR) 2021 impact factor of these journals were analyzed, presenting a range of 2.351 to 8.236 (minimum and maximum scores respectively), demonstrating that research whose objective is the presentation/validation of devices such as eNose in the diagnosis of infected wounds are published in journals or conferences of great relevance worldwide. 
Table 2

General data of the studies included in the sample.

\begin{tabular}{|c|c|c|c|c|c|c|}
\hline ID & Authors/Year & Objectives & Country & $\begin{array}{l}\text { Periodical/ } \\
\text { Qualis (JCR) }\end{array}$ & $\begin{array}{l}\text { Type of } \\
\text { study }\end{array}$ & Database \\
\hline 01 & $\begin{array}{l}\text { H. Sun et al } \\
\text { /2017 }\end{array}$ & $\begin{array}{l}\text { Identification of } \\
\text { Escherichia coli, } \\
\text { Staphylococcus aureus, } \\
\text { Pseudomonas aeruginosa } \\
\text { bacteria in wound } \\
\text { infection using an eNose } \\
\text { system with } 34 \text { sensors }\end{array}$ & China & $\begin{array}{l}\text { IEEE } \\
\text { Transactions on } \\
\text { Industrial } \\
\text { Electronics/ A1- } \\
8,236\end{array}$ & $\begin{array}{l}\text { Experimental } \\
\text { Study }\end{array}$ & IEEE \\
\hline 02 & $\begin{array}{l}\text { P. He et al } \\
/ 2017\end{array}$ & $\begin{array}{l}\text { Present a type of self- } \\
\text { directed learning based on } \\
\text { a sparse autoencoder for } \\
\text { eNose in wound infection } \\
\text { detection. }\end{array}$ & China & $\begin{array}{l}\text { Sensors } \\
\text { (Basel)/ A1- } \\
4,019\end{array}$ & $\begin{array}{l}\text { Experimental } \\
\text { Study }\end{array}$ & Pubmed \\
\hline 03 & $\begin{array}{l}\text { Z. Liang } \\
\text { et al / } 2017\end{array}$ & $\begin{array}{l}\text { To present a new } \\
\text { interference suppression } \\
\text { method based on } \\
\text { removing correlated } \\
\text { information in eNose for } \\
\text { bacterial detection. }\end{array}$ & China & $\begin{array}{l}\text { Analytica } \\
\text { chemistry acta / } \\
\text { A1-5,977 }\end{array}$ & $\begin{array}{l}\text { Experimental } \\
\text { Study }\end{array}$ & Pubmed \\
\hline 04 & $\begin{array}{l}\text { T. Saviauk } \\
\text { et al / } 2018\end{array}$ & $\begin{array}{l}\text { Identify the most common } \\
\text { bacteria species causing } \\
\text { skin infections using } \\
\text { eNose. }\end{array}$ & Finland & $\begin{array}{l}\text { European } \\
\text { Surgical } \\
\text { Research } \\
\text { / B1-2,351 }\end{array}$ & $\begin{array}{l}\text { Experimental } \\
\text { Study }\end{array}$ & Pubmed \\
\hline 05 & $\begin{array}{l}\text { Z. Yuan et al } \\
\text { /2018 }\end{array}$ & $\begin{array}{l}\text { Report the design of an } \\
\text { embedded system using } \\
\text { sensors, a wearable } \\
\text { device, and Al models to } \\
\text { notify patients with open } \\
\text { wounds caused by } \\
\text { diabetes about their } \\
\text { healing status. }\end{array}$ & China & $\begin{array}{l}\text { IEEE Asia } \\
\text { Pacific } \\
\text { Conference } \\
\text { on } \\
\text { Postgraduate } \\
\text { Research in } \\
\text { Microelectronics } \\
\text { and } \\
\text { Electronics }\end{array}$ & $\begin{array}{l}\text { Experimental } \\
\text { Study }\end{array}$ & IEEE \\
\hline 06 & $\begin{array}{l}\text { M. } \\
\text { Haalboom et } \\
\text { al / } 2019\end{array}$ & $\begin{array}{l}\text { Explore whether an eNose, } \\
\text { Aetholab, is able to } \\
\text { discriminate between } \\
\text { infected and uninfected } \\
\text { wounds based on } \\
\text { headspace analysis of } \\
\text { wound swabs. }\end{array}$ & Nederland & $\begin{array}{l}\text { Clinical } \\
\text { microbiology } \\
\text { and infection / } \\
\text { A1-7,117 }\end{array}$ & Pilot Study & Pubmed \\
\hline 07 & $\begin{array}{l}\text { Z. Liang et al } \\
\text { /2019 }\end{array}$ & $\begin{array}{l}\text { Report an eNose system } \\
\text { designed and used for the } \\
\text { detection of bacteria in } \\
\text { wound infection. }\end{array}$ & China & $\begin{array}{l}\text { Sensors } \\
\text { (Basel)/ } \\
\text { A1-4,019 }\end{array}$ & $\begin{array}{l}\text { Experimental } \\
\text { Study }\end{array}$ & Scopus \\
\hline 08 & $\begin{array}{l}\text { C.S. Alvarez } \\
\text { et al / } 2019\end{array}$ & $\begin{array}{l}\text { Experiment with the use of } \\
\text { low-cost gas sensors to } \\
\text { detect bacteria in wounds } \\
\text { using a non-intrusive } \\
\text { technique. }\end{array}$ & Spain & $\begin{array}{l}\text { Sensors } \\
\text { (Basel)/ } \\
\text { A1-4,019 }\end{array}$ & $\begin{array}{l}\text { Experimental } \\
\text { Study }\end{array}$ & Scopus \\
\hline
\end{tabular}




\begin{tabular}{|lllllll|}
\hline ID & Authors/Year & Objectives & Country & $\begin{array}{l}\text { Periodical/ } \\
\text { Qualis (JCR) }\end{array}$ & $\begin{array}{l}\text { Type of } \\
\text { study }\end{array}$ & Database \\
\hline 09 & T. Sun et al & $\begin{array}{l}\text { Integrate two odor } \\
\text { detection technologies - }\end{array}$ & China & $\begin{array}{l}\text { Sensors and } \\
\text { Actuators B: }\end{array}$ & $\begin{array}{l}\text { Experimental } \\
\text { Study }\end{array}$ & Scopus \\
ion mobility spectrometry) & & $\begin{array}{l}\text { Chemical/ } \\
\text { - to discriminate between } \\
\text { three common bacterial } \\
\text { wound infections and non- } \\
\text { infectious by directly } \\
\text { smelling }\end{array}$ & A1-7,100 & & \\
& & & & \\
& & & & \\
& mouse wound samples. & & & \\
\hline
\end{tabular}

\section{Characteristics Of Enoses And Protocol Of Experiments}

Characteristics of eNoses and protocol of experiments

The eNose technology applied in diagnosing infected wounds in the studies included in the sample has their characteristics, where only two were presented as to their type in the publications analyzed (ChemPro 100 and Aetholab), identified in studies ID04 and ID06, respectively [24, 25]. The other researches presented only the characteristics of the eNoses used, their conformation composed of sampling, detection, and control unit.

The basic protocol for collecting data from samples of microorganisms (bacteria) for analysis in an eNose consists initially of growing these bacteria in Petri dishes inside an oven with a defined average temperature. Data is then extracted from the Petri dish with the infectious agent. The aspiration of the VOCs released by these bacteria occurs in a few seconds; the aspirated air is injected into an eNose air chamber with the sensors connected, remaining in this compartment for seconds for the molecules to interact with the sensor surfaces. In the next step, the air content of the chamber is purged through suction and injection of filtered air without VOCs. Throughout the described protocol, data is collected, which are signals from the different sensors inside the device.

The research protocols identified in the studies reviewed, can serve as a basis for performing the proposed methods for analyzing the VOCs released by bacteria more accurately. Each sample used in the identified eNoses devices was subjected to a measurement ranging from 10 minutes (ID04) [24] to 28 minutes (ID02) [26], the most common being a total cycle time of approximately 14 minutes (ID01, ID03, ID07, ID09) [27, 28, 28, 29] (Table 3). The experiments involved a period for baseline collection, whose time ranged from 3 to 5 minutes, a period for sample collection, which ranged from 3 to 4 minutes, and a period for purging the system, which ranged from 4 to 8 minutes. The number of samples ranged from 48 (ID09) [29] to 2664 (ID02) [26].

\section{Type Of Bacteria And Wounds Analyzed}

The bacteria samples used in the analyzed studies represented or simulated infection of seven types of wounds: Infected skin wound (ID01, ID02, ID03, ID04, ID07, ID09) [27, 26, 28, 24, 30, 29], diabetic foot ulcer (ID05, ID06) [31, 25], pressure injury (ID06, ID08) [25, 32], postoperative wound (ID06) [25], traumatic wound (ID06) [25], venous/arterial ulcer (ID06) [25] and Sinus pilonidalis (ID06) [25]. The wide diversity of scenarios makes it possible to evaluate the application of eNose in various real-world wound contexts. 
This also applies to the microorganisms analyzed by eNose, the representation of which can be found in Table 3.15 species of bacteria had their VOC analyzed by eNose, of which the most used were: P. aeruginosa (n: 08), E. coli (n: 07) and Methicillin Susceptible Staphylococcus aureus - MSSA (n: 07). Five studies obtained the bacterial cultures from in vivo experiments (ID02, ID03, ID06, ID07, ID09) [26, 28, 28, 30, 29]. However, only two collected the samples from patients with infected wounds (ID03, ID06) [28, 25].

\section{Artificial Intelligence techniques used to classify models and their effectiveness}

Regarding the Machine Learning algorithms used to classify the trained eNose models, eight classifiers were used, highlighting Support Vector Machine (SVM), used in four studies (ID01, ID03, ID05, ID07) [27, 28, 31, 30]. Different parameter optimization methods were tested in the included studies, mainly Principal Component Analysis (PCA).

Research ID02 [26] presented a new approach to train models using self-directed learning, a new machine learning framework. Other studies (ID03, ID07) $[28,30]$ were concerned with solving some deficiencies that make eNoses face some interference problems, since situations like this can affect system performance and interfere with the experiment.

Some algorithms such as Extreme Learning Machine (ELM), PCA, Orthogonal Signal Correction (OSC), Domain Regularized Component Analysis (DRCA), Domain Correction and Adaptive Extreme Learning Machines (DC-AELM) and Domain Adaptation Extreme Learning Machines (DAELM) were compared. with a new algorithm - Subspace Alignment-Based Interference Suppression (SAIS) [30]. The method is motivated by the different distribution of data collected on different bacterial agents and by the idea of subspatial alignment. The proposed method eliminates the need to add a regularization term and adjust the corresponding parameters [30]. Another new method was used to suppress interference in eNose: Interference Suppression Based on Correlated Information Removal (CIRIS) in another experimental study. It is the "removal of correlated information" rather than removal of uncorrelated information, in order to suppress interference [28].

The efficacy tests presented in the studies were heterogeneous as to whether there was a standard of evaluation. The summary of test values can be identified in Table 3. Sensitivity, specificity, and accuracy values were not presented in all studies, demonstrating a weakness in reporting the results. Thus, only the precision values were considered for analysis purposes.

The average accuracy of eNoses in identifying bacteria present in infected wounds was $95.13 \%$ for the training set, with a minimum value of $78.3 \%$ from the Partial Least Squares Discriminant Analysis (PLSDA) classifier [4] and a maximum of $100 \%$ with the Radial Basis Function (RBF) [27]. On the test set, the average accuracy value of the eNoses was $91.5 \%$, with values of 70.19\% (SVM - PCA) [27] and 100\% (ELM; DC-AELM; DAELM; SAIS; ELM - PCA) [30] representing the minimum and maximum values, respectively. These results cannot be generalized due to the different classification methods used and the different species of bacteria used.

In the ID01 study [24], the fact of verifying the recognition rate of classification without optimization of the sensor array using only SVM stands out, presenting relatively low accuracy values ( $96.32 \%$ - training; $86.56 \%$ - test), in contrast with the application of optimization methods (Table 3), whose LDA was the best method under the circumstances performed (98.16\% - training; $95.19 \%$ - test) and PCA the worst method $(91.18 \%$ - training; $70.19 \%$ test).

We highlight the study of Saviauk [24], whose eNose was able to differentiate MSSA and MRSA with an accuracy of $78 \%$, demonstrating that the differentiation between bacteria of the same genus but sensitive or resistant to 
antibiotics can also be performed through Artificial Intelligence.

Page $10 / 26$ 
Table 3

Main results of the included studies.

\begin{tabular}{|c|c|c|c|c|c|c|c|}
\hline \multirow[t]{3}{*}{ ID } & \multirow[t]{3}{*}{ Wound type } & \multirow[t]{3}{*}{$\begin{array}{l}\text { Analyzed } \\
\text { Bacteria }\end{array}$} & \multirow[t]{3}{*}{$\begin{array}{l}\text { Sample } \\
\text { origin }\end{array}$} & \multirow{3}{*}{$\begin{array}{l}\mathrm{N} \\
\text { (sample)/ } \\
\text { Total } \\
\text { cycle } \\
\text { time } \\
\text { cycle }\end{array}$} & \multirow[t]{3}{*}{$\begin{array}{l}\text { Al } \\
\text { techniques }\end{array}$} & \multicolumn{2}{|c|}{$\begin{array}{l}\text { Efficacy Test Results } \\
\text { (Accuracy) }\end{array}$} \\
\hline & & & & & & & \\
\hline & & & & & & $\begin{array}{l}\text { Training } \\
\text { Phase }\end{array}$ & $\begin{array}{l}\text { Test } \\
\text { (validation) } \\
\text { phase }\end{array}$ \\
\hline 01 & $\begin{array}{l}\text { Infected } \\
\text { cutaneous } \\
\text { wound }\end{array}$ & $\begin{array}{l}\text { E. coli, } \\
\text { MSSA*, P. } \\
\text { aeruginosa }\end{array}$ & In vitro & $\begin{array}{l}480 / \\
14 \\
\text { minutes }\end{array}$ & $\begin{array}{l}\text { Classifier: } \\
\text { Support } \\
\text { Vector } \\
\text { Machine } \\
\text { (SVM); } \\
\text { Linear } \\
\text { Discriminant } \\
\text { Analysis } \\
\text { (LDA) } \\
\text { Optimization } \\
\text { methods: } \\
\text { Principal } \\
\text { Component } \\
\text { Analysis } \\
\text { (PCA); } \\
\text { Genetic } \\
\text { Algorithm } \\
\text { (GA); Wilks' } \\
\text { Statistics; } \\
\text { Mahalanobis } \\
\text { distance }\end{array}$ & $\begin{array}{l}\text { SVM: } \\
\text { 96.32\%. } \\
\text { Sensor } \\
\text { optimization: } \\
\text { LDA: } 98.16 \% \\
\text { Wilks' } \\
\text { statistic: } \\
97.43 \% \\
\text { Mahalanobis } \\
\text { distance: } \\
\text { 97,43\% } \\
\text { GA: } 97.43 \% \\
\text { PCA: } 91.18\end{array}$ & $\begin{array}{l}\text { SVM: } \\
86.54 \% . \\
\text { Sensor } \\
\text { optimization: } \\
\text { LDA: } 95.19 \% \\
\text { Wilks' } \\
\text { statistic: } \\
87.50 \% \\
\text { Mahalanobis } \\
\text { distance: } \\
\text { 93,27\% } \\
\text { GA: } 90.38 \% \\
\text { PCA: } 70.19 \% .\end{array}$ \\
\hline 02 & $\begin{array}{l}\text { Infected } \\
\text { cutaneous } \\
\text { wound }\end{array}$ & $\begin{array}{l}\text { E. coli, } \\
\text { MSSA*, P. } \\
\text { aeruginosa }\end{array}$ & $\begin{array}{l}\text { In vitro } \\
\text { (mouse) }\end{array}$ & $\begin{array}{l}2664 / \\
28 \\
\text { minutes }\end{array}$ & $\begin{array}{l}\text { Classifier: } \\
\text { Radial Basis } \\
\text { Function } \\
\text { (RBF); Partial } \\
\text { Least } \\
\text { Squares } \\
\text { Discriminant } \\
\text { Analysis } \\
\text { (PLSDA). } \\
\text { Optimization } \\
\text { method: } \\
\text { Enhanced } \\
\text { Quantum- } \\
\text { behaved } \\
\text { Particle } \\
\text { Swarm } \\
\text { Optimization } \\
\text { (EQPSO) }\end{array}$ & $\begin{array}{l}\text { RBF: } 100 \% \\
\text { PLSDA: } \\
78,3 \%\end{array}$ & $\begin{array}{l}\text { RBF: } 90 \% \\
\text { PLSDA: } 75 \%\end{array}$ \\
\hline
\end{tabular}

*Methicillin Susceptible Staphylococcus aureus; **Methicillin-resistant Staphylococcus aureus; ${ }^{+}$Not reported results for the training and test set. ${ }^{\square}$ Not reported precision values 


\begin{tabular}{|c|c|c|c|c|c|c|c|}
\hline \multirow[t]{2}{*}{ ID } & \multirow[t]{2}{*}{ Wound type } & \multirow[t]{2}{*}{$\begin{array}{l}\text { Analyzed } \\
\text { Bacteria }\end{array}$} & \multirow[t]{2}{*}{$\begin{array}{l}\text { Sample } \\
\text { origin }\end{array}$} & \multirow{2}{*}{$\begin{array}{l}\mathbf{N} \\
\text { (sample)/ } \\
\text { Total } \\
\text { cycle } \\
\text { time } \\
\text { cycle }\end{array}$} & \multirow[t]{2}{*}{$\begin{array}{l}\text { Al } \\
\text { techniques }\end{array}$} & \multicolumn{2}{|c|}{$\begin{array}{l}\text { Efficacy Test Results } \\
\text { (Accuracy) }\end{array}$} \\
\hline & & & & & & & \\
\hline \multirow[t]{4}{*}{03} & \multirow{4}{*}{$\begin{array}{l}\text { Infected } \\
\text { cutaneous } \\
\text { wound }\end{array}$} & \multirow{4}{*}{$\begin{array}{l}\text { E. coli, } \\
\text { MSSA*, P. } \\
\text { aeruginosa }\end{array}$} & \multirow{4}{*}{$\begin{array}{l}\text { In vitro } \\
\text { (human) }\end{array}$} & $599 /$ & Classifier: & \multirow[t]{4}{*}{ SVM: $100 \%$} & \multirow[t]{4}{*}{ SVM: $97,85 \%$} \\
\hline & & & & \multirow[t]{3}{*}{$\begin{array}{l}14 \\
\text { minutes }\end{array}$} & $\begin{array}{l}\text { Support } \\
\text { Vector } \\
\text { Machine } \\
\text { (SVM) }\end{array}$ & & \\
\hline & & & & & $\begin{array}{l}\text { Optimization } \\
\text { method: } \\
\text { Principal } \\
\text { Component } \\
\text { Analysis } \\
\text { (PCA); } \\
\text { Independent } \\
\text { Component } \\
\text { Analysis } \\
\text { (ICA); }\end{array}$ & & \\
\hline & & & & & $\begin{array}{l}\text { Orthogonal } \\
\text { Signal } \\
\text { Correction } \\
\text { (OSC) }\end{array}$ & & \\
\hline \multirow[t]{2}{*}{04} & \multirow{2}{*}{$\begin{array}{l}\text { Infected } \\
\text { cutaneous } \\
\text { wound }\end{array}$} & \multirow{2}{*}{$\begin{array}{l}\text { MSSA* } \\
\text { MRSA**, S. } \\
\text { pyogenes, } \\
\text { E. coli, } P . \\
\text { aeruginosa, } \\
C . \\
\text { perfringens }\end{array}$} & \multirow[t]{2}{*}{ In vitro } & \multirow[t]{2}{*}{$138 /-$} & & \multirow[t]{2}{*}{$\square$} & \multirow[t]{2}{*}{ LDA: 78\% } \\
\hline & & & & & $\begin{array}{l}\text { Linear } \\
\text { Discriminant } \\
\text { Analysis } \\
\text { (LDA) }\end{array}$ & & \\
\hline \multirow[t]{5}{*}{05} & \multirow[t]{5}{*}{$\begin{array}{l}\text { Diabetic foot } \\
\text { ulcer }\end{array}$} & \multirow{5}{*}{$\begin{array}{l}M S S A *, S . \\
\text { epidermidis, } \\
P . \\
\text { aeruginosa }\end{array}$} & \multirow[t]{5}{*}{-} & \multirow[t]{5}{*}{$2000 /$} & \multirow{5}{*}{$\begin{array}{l}\text { Classifier: } \\
\text { Support } \\
\text { Vector } \\
\text { Machine } \\
\text { (SVM) }\end{array}$} & \multicolumn{2}{|c|}{$\begin{array}{l}\text { Precision of basic } \\
\text { parameters: }\end{array}$} \\
\hline & & & & & & \multicolumn{2}{|c|}{$\begin{array}{l}\text { Temperature: error - } 0.9 \% \text {; } \\
\text { Humidity: error }-2.3 \% \text {; } \mathrm{SpO} 2 \text { : } \\
\text { error - 5.8\%; Pressure: error - } \\
1.5 \%\end{array}$} \\
\hline & & & & & & \multicolumn{2}{|c|}{ Gas sensors: } \\
\hline & & & & & & \multicolumn{2}{|c|}{$\begin{array}{l}\text { Ethanol concentration: error - } \\
8.7 \% \text {; Aldehyde concentration } \\
-12.8 \% \text {; Sulfur compound } \\
\text { concentration }-3.4 \%\end{array}$} \\
\hline & & & & & & \multicolumn{2}{|c|}{ Prediction status: $2.8 \%$. } \\
\hline
\end{tabular}

*Methicillin Susceptible Staphylococcus aureus; **Methicillin-resistant Staphylococcus aureus; ${ }^{+}$Not reported results for the training and test set. ${ }^{\square}$ Not reported precision values 


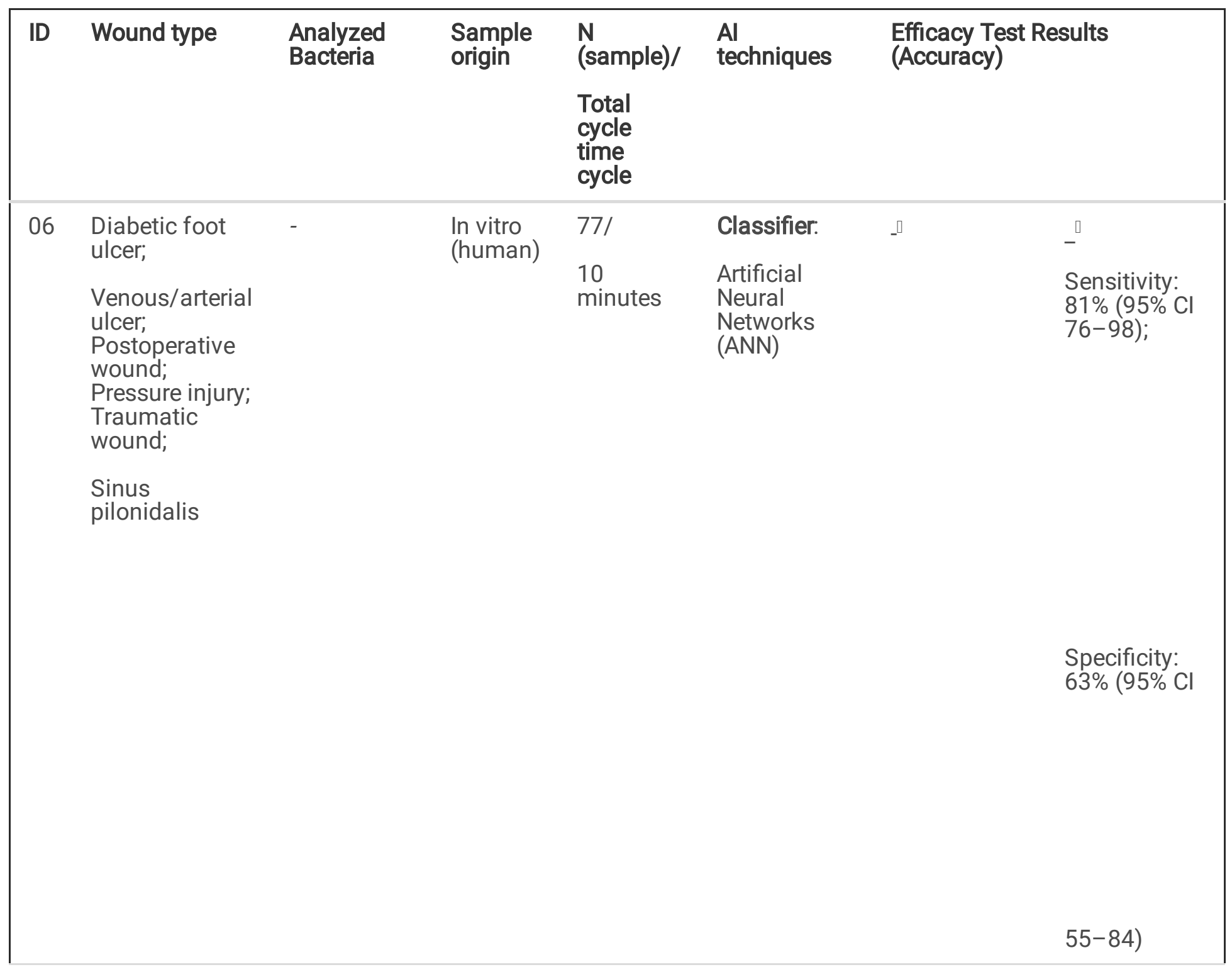

*Methicillin Susceptible Staphylococcus aureus; ** Methicillin-resistant Staphylococcus aureus; ${ }^{+}$Not reported results for the training and test set. ${ }^{\square}$ Not reported precision values 


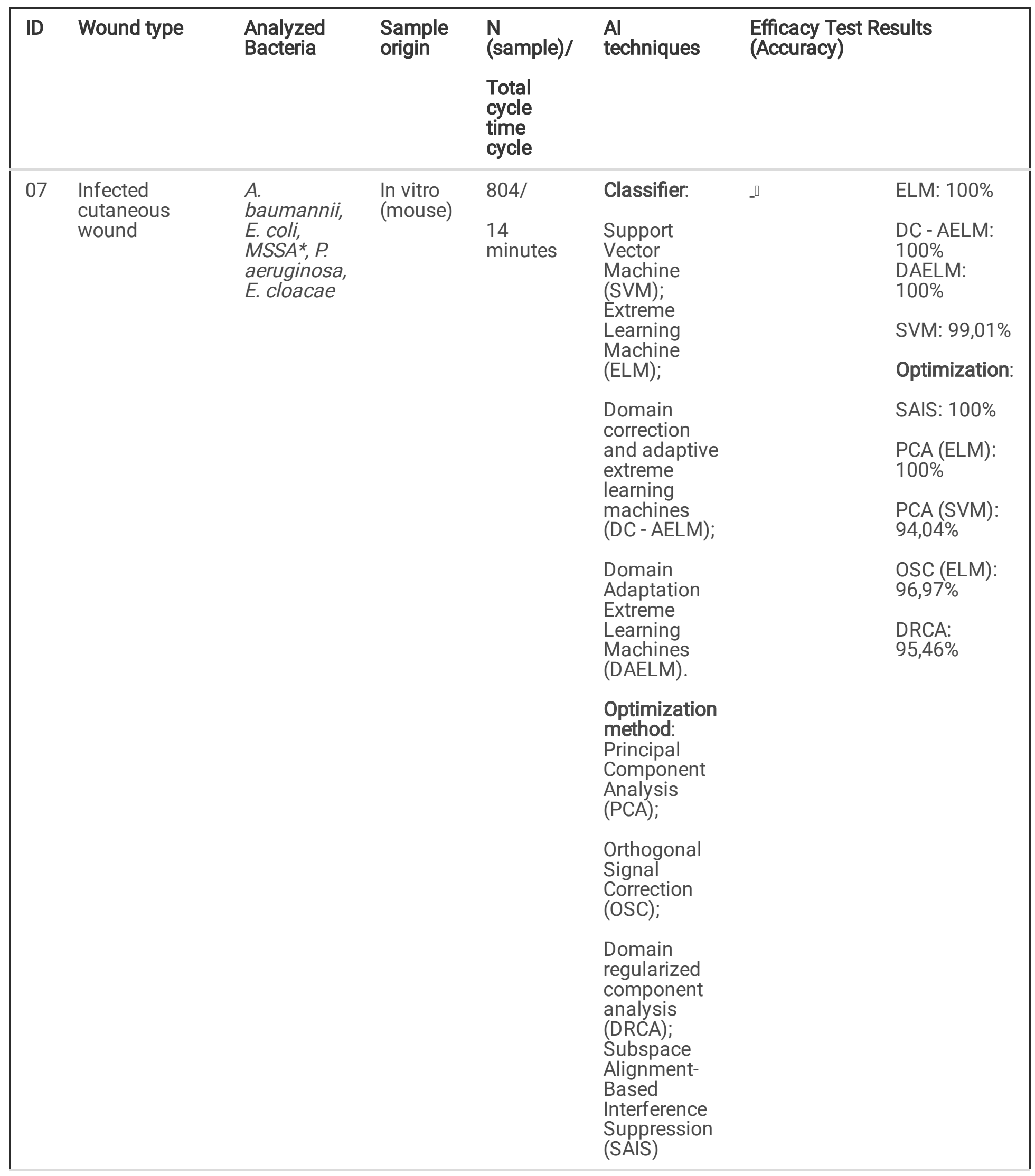

*Methicillin Susceptible Staphylococcus aureus; **Methicillin-resistant Staphylococcus aureus; ${ }^{+}$Not reported results for the training and test set. ${ }^{\square}$ Not reported precision values 


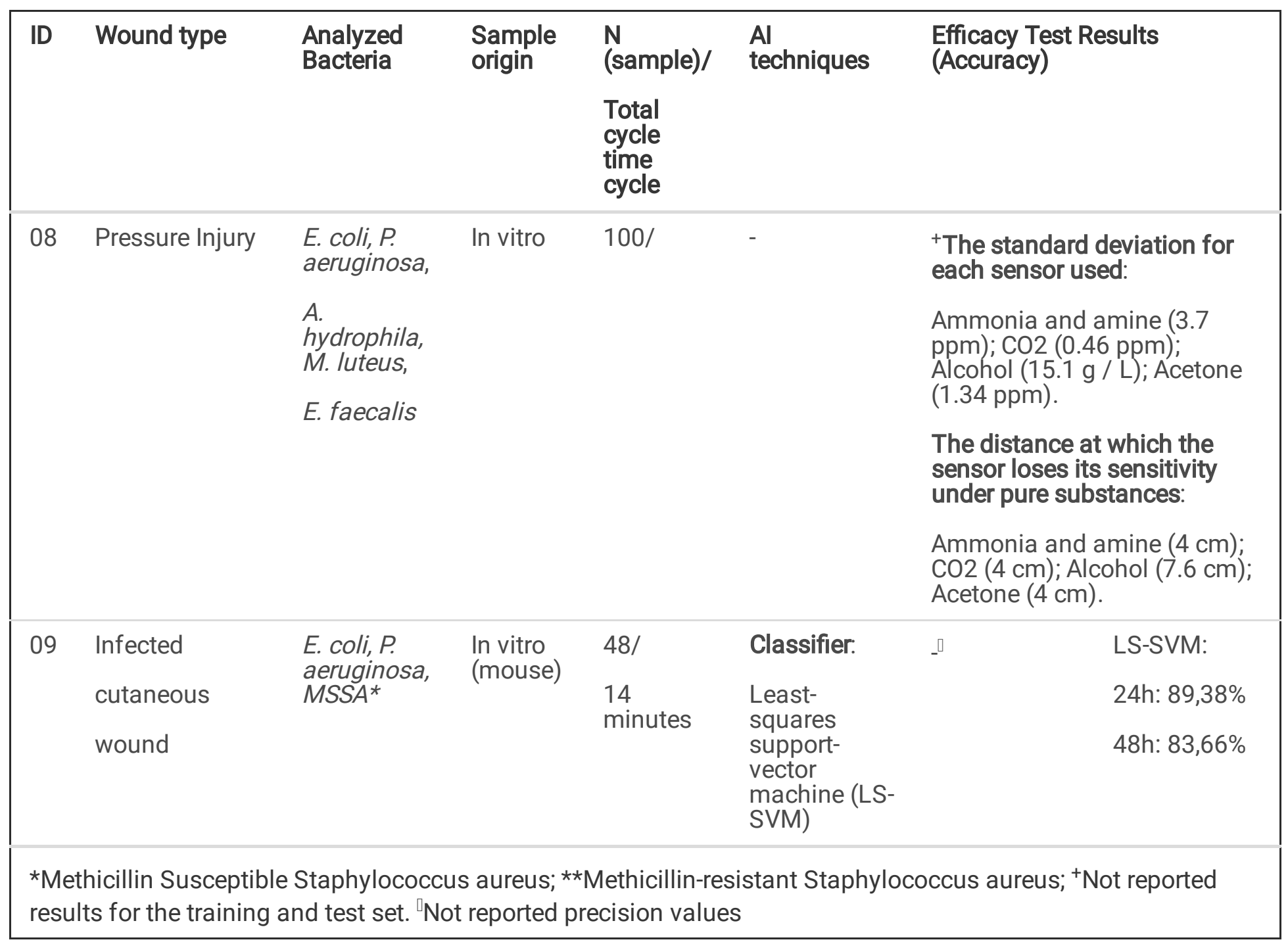

\section{Main primary gas sensors used in eNoses applied to the diagnosis of infected wounds}

By analyzing the most commonly used bacteria for the testing of eNoses in the sample studied, the main volatile products emitted by these microorganisms and the primary gas sensors to be used were verified for criteria for formulating new study protocols as presented in Table 4. Primary gas sensors are sensitive to typical metabolites of common bacteria in wound infections. 
Table 4

Main gas sensors are sensitive to typical metabolites of common bacteria in wound infections.

\begin{tabular}{|c|c|c|}
\hline Pathogens & $\begin{array}{l}\text { Volatiles released } \\
\text { by the pathogen }\end{array}$ & $\begin{array}{l}\text { Main gas sensors } \\
\text { suggested for pathogens }\end{array}$ \\
\hline & \multicolumn{2}{|l|}{ Isobutane, isovaleric acid, } \\
\hline Staphylococcus aureus & acetic acid & $\begin{array}{l}\text { TGS822 (alcohol and organic } \\
\text { solvent), }\end{array}$ \\
\hline \multirow{4}{*}{$\begin{array}{l}\text { Staphylococcus } \\
\text { epidermidis }\end{array}$} & Acid and alcohol & \multirow{5}{*}{$\begin{array}{l}\text { TGS823 (ethanol), } \\
\text { TGS826 (ammonia } \\
\text { and amines), }\end{array}$} \\
\hline & & \\
\hline & Pyruvate, hydrogen cyanide, & \\
\hline & 1-undecene, 2-butanone, & \\
\hline \multirow{4}{*}{$\begin{array}{l}\text { Pseudomonas } \\
\text { aeruginosa }\end{array}$} & 4-methylquinazoline & \\
\hline & & \multirow{3}{*}{$\begin{array}{l}\text { TGS2602 (ammonia } \\
\text { and hydrogen sulfide), } \\
\text { TGS2600 (air pollutants }\end{array}$} \\
\hline & & \\
\hline & & \\
\hline \multirow[t]{3}{*}{ Escherichia coli } & \multirow{3}{*}{$\begin{array}{l}\text { Methanol, pentanol, ethyl acetate, propanol, } \\
\text { butanol, } \\
\text { acetone, propionic acid }\end{array}$} & MQ135 (CO2), \\
\hline & & MQ138 (acetone) \\
\hline & & MQ3 (alcohol) \\
\hline
\end{tabular}

\section{Assessment of the quality level of the studies included in the review}

The methodological quality assessments of the included studies are summarized in Fig. 3, with a minimum score of 5 and a maximum score of 9 on a scale of 0 to 10. Three studies (ID05, ID07, and ID08) [31, 30, 32] were classified as level $B$, for scoring less than 6; these studies did not present a clear description of the results obtained in the eNose efficacy tests, such as sensitivity, specificity, and accuracy, and did not clearly explain the methods proposed for analyzing the databases developed.

In contrast, the other studies (ID01, ID02, ID03, ID04, ID06, and ID09) [27, 26, 28, 24, 25, 29] scored above 6 and were classified as level A, demonstrating the care taken by the researchers in the context of the study, as well as in defining the protocols of the experiments and presenting the results as clearly as possible.

\section{Discussion}

In the present study, according to the articles selected, it was observed that research involving the use of eNose for the diagnosis of bacteria-infected wounds started to receive more attention from the scientific community in the last four years, with greater emphasis in the last two years. Among the Al techniques used to train the models discussed in this review, SVM is the most common. It is a popular machine learning method for classification, regression, and other learning tasks [33]. When applied to eNose technology, good results for complex odor discrimination have been achieved by this algorithm $[27,28,31,30]$. 
In the reviewed studies, the researchers applied optimization methods to the eNose sensor array to improve accuracy results on the training and test datasets. Overall, applying the classifiers alone resulted in lower-thanexpected accuracy values compared to the satisfactory results using optimization methods. In some studies [27, 28, 30], the PCA method obtained the worst results. In this perspective, it is known that it is an unsupervised dimensionality reduction method, in which the projection direction with the maximum variation of the data set is mainly considered, and the class information is not fully used, this being one of the main reasons for the unsatisfactory results of the sensor array optimized by this method [27]. In this sense, class information plays a crucial role in optimizing an eNose sensor array, favoring better accuracy and efficacy results and consequently contributing to a better classification of common bacteria in wound infections.

When analyzing the efficacy test results of the identified eNoses, high average accuracy was found for both the training set and test set models. Thus, to develop a robust algorithm that allows real-time measurements, an eNose needs prior knowledge of the data (training phase) in order to avoid a fallacy in the analysis of Vocs released during an actual diagnosis of wound infection [34]. However, it was found that some studies did not make clear the data regarding this phase, leaving the final efficacy result unclear, despite the high value found in the test set.

It is noteworthy that some eNoses have achieved satisfactory results, including the ability to differentiate between bacteria of the same genus but sensitive or resistant to antibiotics. Among the most frequent pathogens in wound infection, $S$. aureus is the main causative agent involved, developing resistance to many antibiotics in recent years [35]. In an experimental study by Saviauk et al. [24], the eNose system was able to differentiate between two types of S. aureus (MSSA and the MRSA) with a sensitivity of $83 \%$, a specificity of $100 \%$, and an overall accuracy of $91 \%$.

Results like this have raised the interest of the scientific and medical engineering community in using eNoses to more quickly diagnose MRSA infections. This is because this pathogen has caused a major health problem worldwide, so that it is estimated that MRSA infections in the healthcare environment alone affected more than 150,000 patients annually in the European Union, with an additional cost of 380 million euros [36].

Regarding the gas sensors present in eNoses, those with high sensitivity to bacteria in infected wounds were considered in subsection 3.1.7. These microorganisms are known to have characteristic odors and have a distinct metabolism, part of which results in the production of specific VOCs that may be sensitive to any of the sensors present in eNoses [37].

The four bacterial species most analyzed in the studies in this review (S. aureus, S. epidermidis, $P$. aeruginosa, and $E$. coli) have several biomarkers that qualify for clinical investigation. However, some such as methanol, pentanol, butanol, acetone, and alcohol are produced by all of these microorganisms and are extremely relevant to the correct choice of sensors used in eNoses [37].

These sensors are selected according to their sensitivities to the metabolites released by these microorganisms and are one of the basic elements of the eNose tool. In this perspective, researchers point out that it should possess some crucial features such as high cross-sensitivity, specificity, stability, reproducibility, the low time between response and recovery, low moisture sensitivity, easy calibration, and robustness [38].

The great interest of researchers in studying the eNose technology as a diagnostic tool is remarkable, especially regarding infections present in skin lesions. However, after analyzing the publications included in this review, it was found that there are some limitations in the studies that use eNose technology as a possible non-invasive diagnostic tool. Most of the studies did not obtain samples directly from patients but bacteria colonized in the laboratory or 
animal models. They may influence the final results of applicability in a real clinical diagnosis because the detection effect will be weak when the prediction model established by the experimental data of the bacterial culture solution is directly used for human detection, which may be caused by the difference in the statistical distribution of the sensor array data collected under different types of sample carriers.

Another limitation identified relates to the lack of standardization of research protocols, which resulted in distinct analyses of the results involved. In this regard, researchers should also adopt a strict sampling method protocol to achieve comparable results across studies and improve diagnostic accuracy. Furthermore, an external validation (involves a validation set with newly recruited patients to assess diagnostic accuracy) of the results should be encouraged in studies to confirm and give robustness to the results obtained $[39,40]$. Unfortunately, no studies have performed this type of validation.

\section{Limitations}

Some limitations of this review were: a) only studies published in English, Portuguese, and Spanish were considered, so relevant studies published in other languages may have been disregarded; $b$ ) the initial search filter was limited to the title and abstract of the articles, which may theoretically have excluded some studies that could be included in the review.

\section{Conclusion}

The use of eNose to identify bacteria is a recent and promising method in the medical field because it allows a fast and accurate diagnostic aid for various types of infections. In wound care, this technology has had several investments in research since the main characteristic of infection is through the odor released by these microorganisms, raising a new sphere of future treatment of these patients, increasing diagnostic accuracy and consequently reducing complications and costs resulting from hospitalization.

In this systematic review, few studies participated in the sample, given the recent deployment of the eNose in wound diagnostic aid. It was observed that eNoses devices may have wide applicability in the diagnosis of these infections, through their high efficacy values. In the studies analyzed, it was found that both in the training sets and in the test sets, for validation of the proposed models, there was a high accuracy of these devices in identifying bacteria. It was found that the application of sensor optimization methods increased the accuracy values in the experiments, in contrast to using only the classification algorithms.

The number of bacteria samples analyzed were sufficient for accurate data analysis, as were the various types of Machine Learning algorithms used to classify the developed computational models (eight classifiers), the most common being the use of Support Vector Machine. In this perspective, some researchers have focused on solving some pending issues related to possible interferences in eNoses, already thinking about the application of these devices in hospital units, since these environments have substances that can decrease the accuracy of eNose.

However, some of the studies analyzed presented some limitations that may have influenced their final results; a large portion of the research focused their analysis on in vitro or in vivo experiments (animals), raising the need for research in appropriate environments such as hospitals, so that the accuracy of the application of Machine Learning algorithms are higher and real problems can be identified that can significantly interfere with the quality of identification of these bacteria. Other limitations were found, such as the time of the analysis process after the culture period, where it was observed that no study performed analyses with a period of less than 24 hours. 
Based on these limitations, new experimental research can be carried out based on the results analyzed in this review, incorporating more robust methods of data analysis that can identify the bacteria in situ, as well as the use of advanced Machine Learning methods such as deep neural networks, so that the accuracy in the diagnostic aid of infected wounds can be greater and faster.

\section{Abbreviations}

AMR

Antimicrobial Resistance

CAPES

Coordination for the Improvement of Higher Level Personnel

CASP

Critical Appraisal Skills Programme

CIRIS

Correlated Information Removing Based Interference Suppression

DC-AELM

Domain correction and adaptive extreme learning machines

DRCA

Domain regularized component analysis

ELM

Extreme Learning Machine

MRSA

Methicillin-resistant Staphylococcus aureus

MSSA

Methicillin Susceptible Staphylococcus aureus

OSC

Orthogonal Signal Correction

PCA

Principal Component Analysis

PLSDA

Partial Least Squares Discriminant Analysis

PRISMA

Preferred Reporting Items for Systematic Reviews and Meta-Analyses

RBF

Radial Basis Function

SAIS

Subspace Alignment-Based Interference Suppression

SVM

Support Vector Machine

VOC

Volatile Organic Compounds.

\section{Declarations}


Not applicable.

\section{Consent for publication}

Not applicable.

\section{Availability of data and materials}

The datasets used during the present study are available from Additional Files.

\section{Competing interests}

The authors declare that they have no competing interests.

\section{Funding}

This research did not receive any specific grant from funding agencies in the public, commercial, or not-for-profit sectors.

\section{Author's contributions}

JWAN: Conceptualization, Methodology, Software, Validation, Data curation, Formal analysis, Writing - original draft, Writing - revision \& editing, Visualization. GSLR and MLB: Methodology, Software, Validation, Formal analysis, Writing - original draft, Visualization, Research. RRS: Conceptualization, Writing - original draft, Writing - revision and editing. ICRVS and LMA: Supervision, Conceptualization, Methodology, Data curation, Writing - original draft, Writing - revision \& edition, Visualization, Project management. All authors approved the final version.

\section{Acknowledgements}

Not applicable.

\section{References}

1. Roque GSL, Souza RR, Nascimento JWA, Filho ASC, Queiroz SRM, Santos ICRV. Content validation and usability of a chatbot of guidelines for wound dressing. Int J Med Inform. 2021; 151: 104473.

https://doi.org/10.1016/j.ijmedinf.2021.104473

2. Sun Y, Ogawa R, Xiao BH, Feng YX, Wu Y, Chen LH, Gao XH, Chen HD. Antimicrobial photodynamic therapy in skin wound healing: A systematic review of animal studies. Int Wound J. 2019; 17(2):285-299. https://doi.org/10.1111/iwj.13269

3. Nussbaum SR, Carter MJ, Fife CE, Vanzo JD, Haught R, Nusgart M, Cartwright D. An economic evaluation of the impact, cost, and medicare policy implications of chronic nonhealing wounds. Value in Health. 2018; 21(1): 2732. http://dx.doi.org/10.1016/j.jval.2017.07.007

4. Sen CK. Human Wounds and Its Burden: An Updated Compendium of Estimates. Adv Wound Care. 2019; 8(2): 39-48. http://dx.doi.org/10.1089/wound.2019.0946

5. Lindholm C, Searle R. Wound management for the 21 st century: combining effectiveness and efficiency. Int Wound J. 2016; 13: 5-15. https://doi.org/10.1111/iwj.12623 
6. Guest JF, Ayoub N, Mcllwraith T, Uchegbu I, Gerrish A, Weidlich D, Vowden K, Vowden P. Health economic burden that wounds impose on the national health service in the UK. BMJ open. 2015; 5(12): e009283.

https://doi.org/10.1136/bmjopen-2015-009283

7. Giacometti A, Cirioni O, Schimizzi A, Del Prete MS, Barchiesi F, D’Errico MM, Petrelli E, Scalise G. Epidemiology and microbiology of surgical wound infections. J Clin Microbiol. 2000; 38(2): 918-922.

https://doi.org/10.1128/jcm.38.2.918-922.2000

8. Dryden MS. Skin and soft tissue infection: microbiology and epidemiology. Int J Antimicrob Agents. 2009; 34: 2-7. https://doi.org/10.1016/s0924-8579(09)70541-2

9. Múñez E, Ramos A, Espejo TA, Vaqué J, Sáchez-Payá J, Pastor V, Asensio A. Microbiology of surgical site infections in abdominal tract surgery patients. Cir Esp. 2011; 89: 606-612.

https://doi.org/10.1016/j.ciresp.2011.05.008

10. Daulton E, Wicaksono A, Bechar J, Covington JA, Hardwicke J. The detection of wound infection by ion mobility chemical analysis. Biosensors. 2020; 10(3): 19. https://dx.doi.org/10.3390\%2Fbios10030019

11. Chang SS, Hsieh WH, Liu TS, Lee SH, Wang CH, Chou HC, Yeo YH, Tseng CP, Lee CC. Multiplex PCR system for rapid detection of pathogens in patients with presumed sepsis-a systemic review and meta-analysis. PloS one. 2013; 8(5): e62323. https://doi.org/10.1371/journal.pone.0062323

12. Giraud-Gatineau A, Texier G, Garnotel E, Raoult D, Chaudet H. Insights into subspecies discrimination potentiality from bacteria malditof mass spectra by using data mining and diversity studies. Front. Microbiol. 2020; 11: 1931. https://doi.org/10.3389/fmicb.2020.01931

13. Reddy M, Gill SS, Wu W, Kalkar SR, Rocha PA. Does this patient have an infection of a chronic wound? JAMA. 2012; 307(6): 605-611. https://doi.org/10.1001/jama.2012.98

14. Boots AW, Bos LD, van der Schee MP, van Schooten FJ, Sterk PJ. Exhaled molecular fingerprinting in diagnosis and monitoring: validating volatile promises. Trends Mol Med. 2015; 21(10): 633-644.

https://doi.org/10.1016/j.molmed.2015.08.001

15. de Melo Lisboa H, Page T, Guy C. Odor management: fundamentals of electronic nose. Eng Sanit Ambient. 2009; 14(1): 9-18. https://doi.org/10.1590/S1413-41522009000100002

16. Gardner JW, Bartlett PN. A brief history of electronic noses. Sensors and Actuators B: Chemical. 1994; 18(1-3): 210-211.

17. Borowik P, Adamowicz L, Tarakowski R, Waclawik P, Oszako T, Slusarski S, Tkaczyk M. Development of a lowcost electronic nose for detection of pathogenic fungi and applying it to fusarium oxysporum and rhizoctonia solani. Sensors (Basel). 2021; 21(17): 5868. https://doi.org/10.3390/s21175868

18. Pavlou AK, Turner AP. Sniffing out the truth: clinical diagnosis using the electronic nose. Clin Chem Lab Med. 2000; 38(2): 99-112. https://doi.org/10.1515/cclm.2000.016

19. Maniscalco M, Motta A. Clinical and inflammatory phenotyping: Can electronic nose and nmr-based metabolomics work at the bedside? Arch Med Res. 2018; 49(1): 74-76.

https://doi.org/10.1016/j.arcmed.2018.04.001

20. Liao YH, Wang ZC, Zhang FG, Abbod MF, Shih CH, Shieh JS. Machine learning methods applied to predict ventilator-associated pneumonia with pseudomonas aeruginosa infection via sensor array of electronic nose in intensive care unit. Sensors (Basel). 2019; 19(8): 1866. https://doi.org/10.3390/s19081866

21. Rodríguez-Aguilar M, León-Martínez LD, Zamora-Mendoza BN, Comas-García A, Palomares SEG, GarcíaSepúlveda CA, Alcántara-Quintana LE, Díaz-Barriga F, Flores-Ramírez. Comparative analysis of chemical breath- 
prints through olfactory technology for the discrimination between SARS-CoV-2 infected patients and controls. Clin Chim Acta. 2021; 519: 126-132. https://doi.org/10.1016/j.cca.2021.04.015

22. Haalboom M. Chronic wounds: innovations in diagnostics and therapeutics. Current medicinal chemistry. 2018; 25(41): 5772-5781. https://doi.org/10.2174/0929867324666170710120556

23. Moher D, Shamseer L, Clarke M, Ghersi D, Liberati A, Petticrew M, Shekelle P, Stewart LA, Prisma-P Group. Preferred reporting items for systematic review and meta-analysis protocols (PRISMA-P) 2015 statement. Syst. Rev. 2015; 4(1): 1-9. https://doi.org/10.1186/2046-4053-4-1

24. Saviauk T, Kiiski JP, Nieminen MK, Tamminen NN, Roine AN, Kumpulainen PS, Hokkinen LJ, Karjalainen MT, Vuento RE, Aittoniemi JJ, Lehtimaki TJ, Oksala NK. Electronic nose in the detection of wound infection bacteria from bacterial cultures: a proof-of-principle study. Eur Surg Res. 2018; 59(1-2): 1-11.

https://doi.org/10.1159/000485461

25. Haalboom M, Gerritsen J, van der Palen J. Differentiation between infected and non-infected wounds using an electronic nose. Clin Microbiol Infect. 2019; 25(10). https://doi.org/10.1016/j.cmi.2019.03.018

26. He P, Jia P, Qiao S, Duan S. Self-taught learning based on sparse autoencoder for e-nose in wound infection detection. Sensors (Basel). 2017; 17(10): 2279. https://doi.org/10.3390/s17102279

27. Sun H, Tian F, Liang Z, Sun T, Yu B, Yang SX, He Q, Zhang L, Liu X. Sensor array optimization of electronic nose for detection of bacteria in wound infection. IEEE Transactions on Industrial Electronics. 2017; 64(9): 73507358. https://doi.org/10.1109/TIE.2017.2694353

28. Liang Z, Tian F, Zhang C. A correlated information removing based interference suppression technique in electronic nose for detection of bacteria. Anal. Chim. Acta. 2017; 986: 145-152.

https://doi.org/10.1016/j.aca.2017.07.028

29. Sun T, He J, Qian S, Zheng Y, Zhang K, Luo J, Tian F. Collaborative detection for wound infections using electronic nose and faims technology based on a rat wound model. Sensor Actuat B-Chem. 2020; 320: 128595. https://doi.org/10.1016/j.snb.2020.128595

30. Liang Z, Tian F, Zhang C, Yang L. A novel subspace alignment-based interference suppression method for the transfer caused by different sample carriers in electronic nose. Sensors (Basel). 2019; 19(22): 4846. https://doi.org/10.3390/s19224846

31. Yuan Z, Huang J, Zhao Z, Zahid A, Heidari H, Ghannam R, Abbasi QH. A compact wearable system for detection and estimation of open wound status in diabetic patient. 2018 IEEE Asia Pacific Conference on Postgraduate Research in Microelectronics and Electronics (PrimeAsia). 2018: 60-63.

https://doi.org/10.1109/PRIMEASIA.2018.8598064

32. Alvarez CS, Sierra-Sosa D, Garcia-Zapirain B, Yoder-Himes D, Elmaghraby A. Detection of volatile compounds emitted by bacteria in wounds using gas sensors. Sensors (Basel). 2019; 19(7): 1523.

https://doi.org/10.3390/s19071523

33. You D, Gao X, Katayama S. WPD-PCA-Based laser welding process monitoring and defects diagnosis by using FNN and SVM. IEEE Trans. Ind. Electron. 2015; 62(1): 628-636. https://doi.org/10.1109/TIE.2014.2319216

34. Bruins MG. Transferable odor differentiation models for infectious disease diagnostics. Erasmus MC: University Medical Center; Rotterdam; 2014. http://hdl.handle.net/1765/50566

35. Tsige Y, Tadesse S, Eyesus TG, Tefera MM, Amsalu A, Menberu MA, Gelaw B. Prevalence of Methicillin-Resistant Staphylococcus aureus and Associated Risk Factors among Patients with Wound Infection at Referral Hospital, Northeast Ethiopia. J Pathog. 2020: 1-7. https://dx.doi.org/10.1155\%2F2020\%2F3168325

Page 22/26 
36. Kock R, Becker K, Cookson B, van Gemert-Pijnen E, Harbarth S, Kluytmans J, Mielke M, Peters G, Skov RL, Struelens MJ, Tacconelli E, Torné AN, Witte W, Friedrich AW. Methicillin-resistant staphylococcus aureus (MRSA): burden of disease and control challenges in Europe. Eurosurveillance. 2010; 15(41): 19688. https://doi.org/10.2807/ese.15.41.19688-en

37. Bos LDJ, Sterk PJ, Schultz MJ. Volatile metabolites of pathogens: a systematic review. PLoS Pathog. 2013; 9(5): e1003311. https://dx.doi.org/10.1371\%2Fjournal.ppat.1003311

38. Behera B, Joshi R, Vishnu GKA, Bhalerao S, Pandya HJ. Pandya Electronic nose: A non-invasive technology for breath analysis of diabetes and lung cancer patients. J Breath Res. 2019; 13(2): 024001. https://doi.org/10.1088/1752-7163/aafc77

39. Fens N, Roldaan AC, van der Schee MP, Boksem RJ, Zwinderman AH, Bel EH, Sterk PJ. External validation of exhaled breath profiling using an electronic nose in the discrimination of asthma with fixed airways obstruction and chronic obstructive pulmonary disease. Clin Exp Allergy. 2011; 41(10): 1371-1378.

https://doi.org/10.1111/j.1365-2222.2011.03800.x

40. Yusuf N, Zakaria A, Omar MI, Md Shakaff AY, Masnan MJ, Kamarudin LM, Rahim NA, Zakaria NZI, Abdullah AA, Othman A, Yasin S. In-vitro diagnosis of single and poly microbial species targeted for diabetic foot infection using e-nose technology. BMC Bioinformatics. 2015; 16: 158.

\section{Figures}



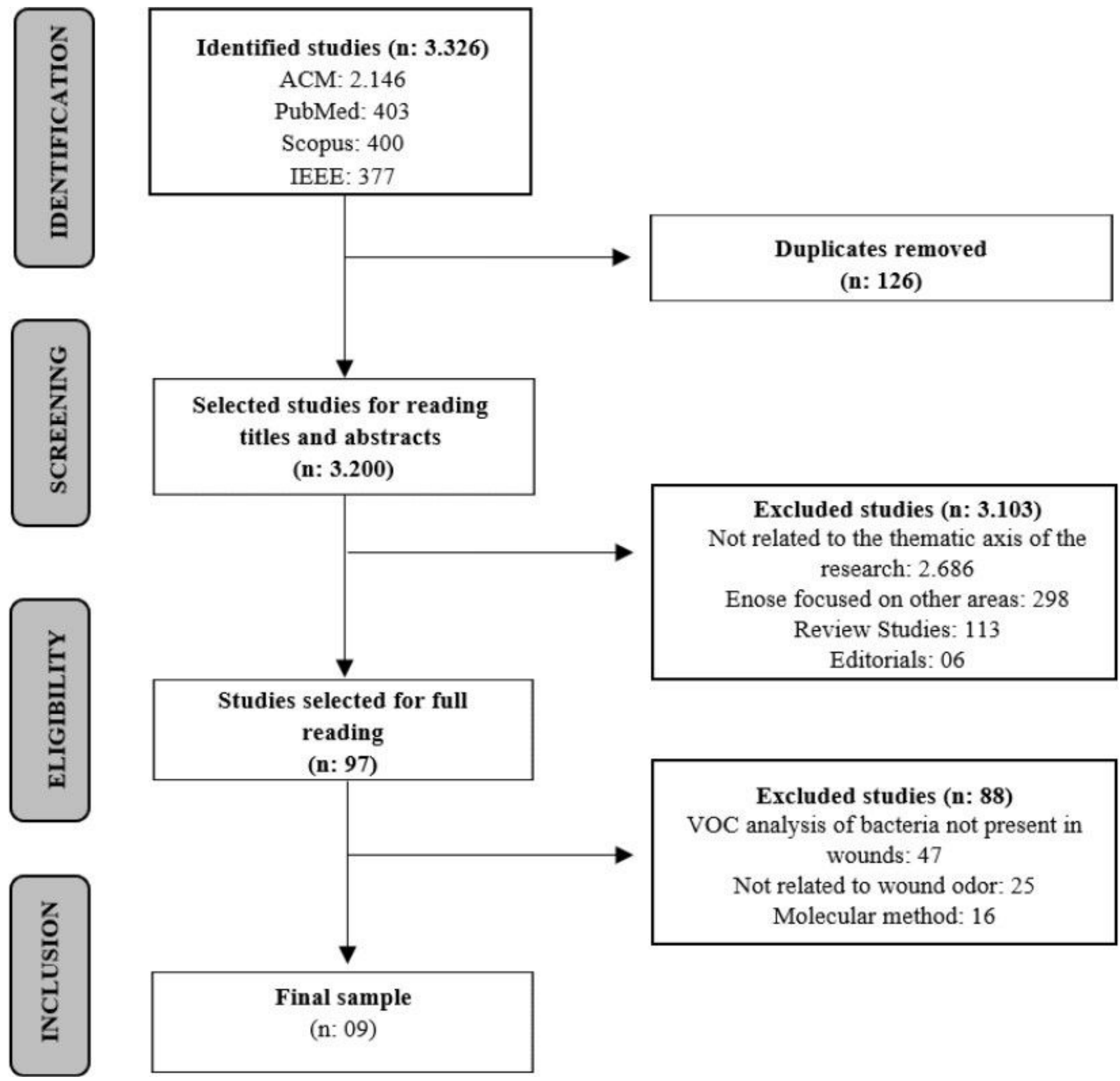

Excluded studies (n: 88)

VOC analysis of bacteria not present in wounds: 47

Not related to wound odor: 25

Molecular method: 16

Figure 1

Flow chart for the identification, screening, and eligibility of studies based on PRISMA. 


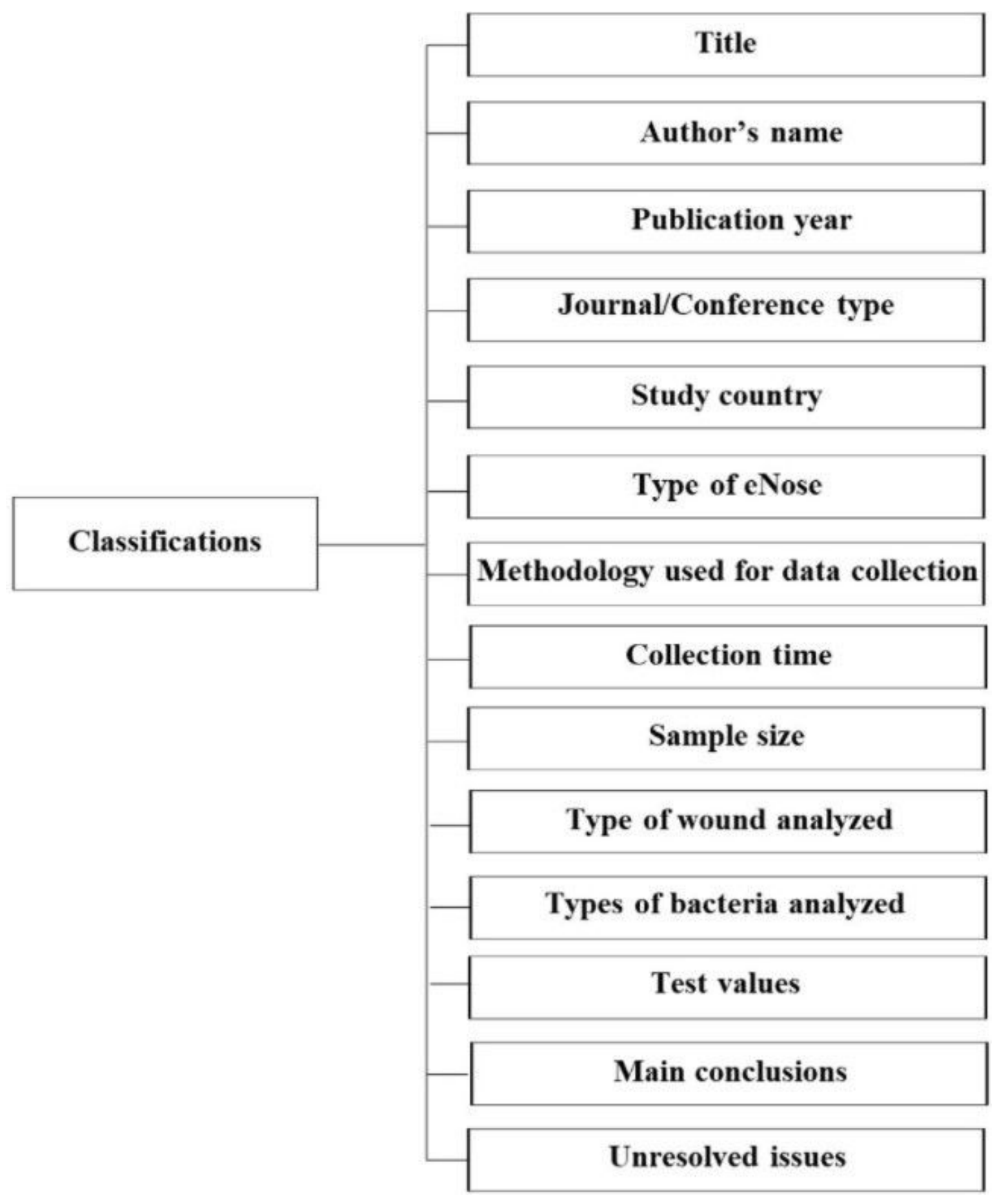

Figure 2

The categories of reviewed articles 


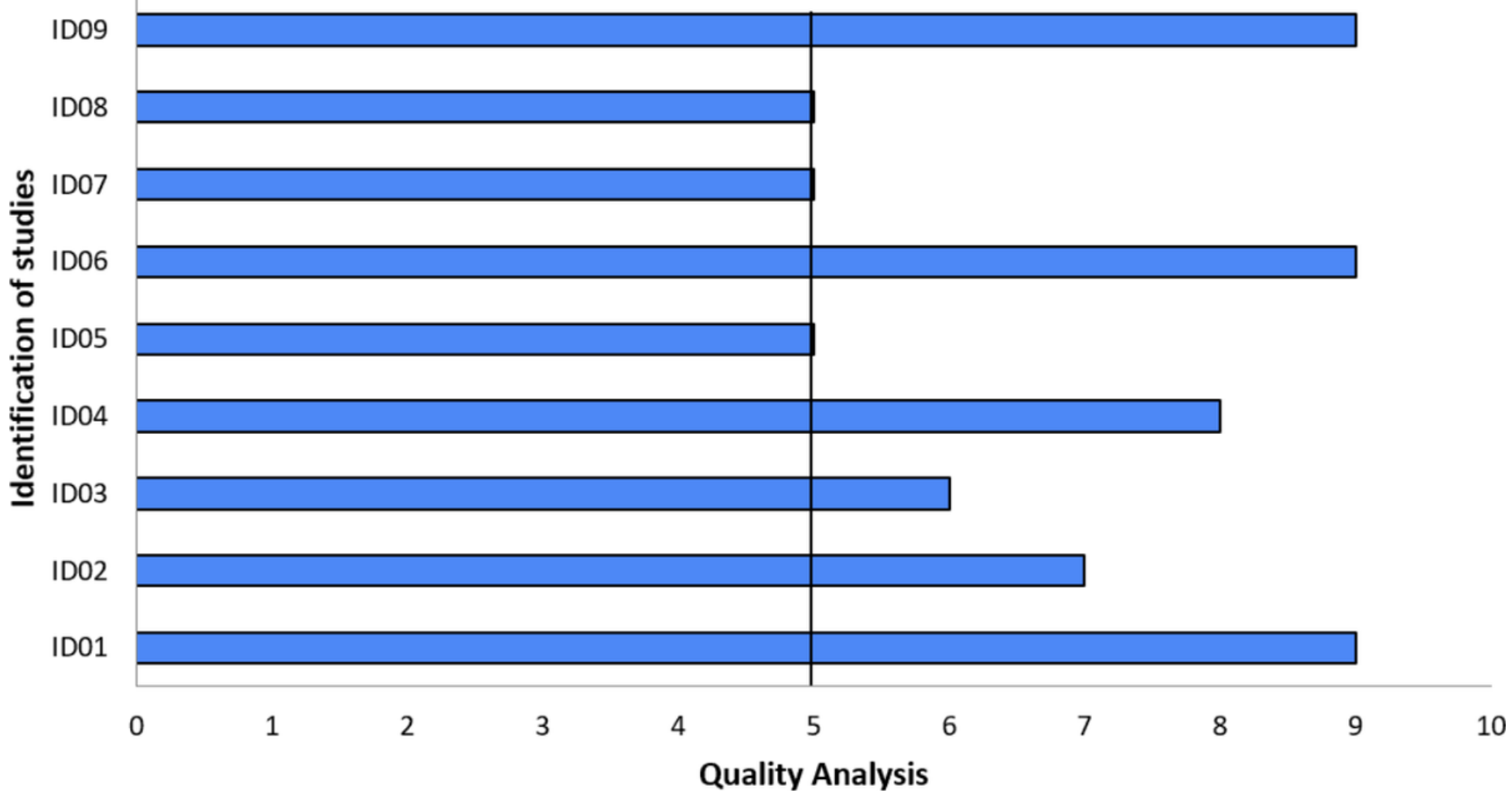

Figure 3

Quality of the studies

\section{Supplementary Files}

This is a list of supplementary files associated with this preprint. Click to download.

- AppendixA.pdf

- AppendixB.pdf 